\title{
HUBUNGAN LINGKUNGAN KERJA DENGAN GEJALA SICK BUILDING SYNDROME PADA PEGAWAI BPJS KESEHATAN DEPOK TAHUN 2019
}

\author{
Annisa Nanda Asri ${ }^{1}$, Rafiah Maharani Pulungan ${ }^{2}$, Azizah Musliha Fitri ${ }^{3}$ \\ ${ }_{1,2,3}$ Fakultas Ilmu Kesehatan Universitas Pembangunan Nasional "Veteran" Jakarta \\ annisananda7@gmail.com
}

\begin{abstract}
Sick building syndrome (SBS) is a collection of complaints felt by employees who work in rooms with poor air quality. BPJS Kesehatan Depok City employees work in a closed room with poor lighting and work climate so that it has the potential to experience symptoms such as fatigue, headaches, and back pain. The purpose of this study was to analyze the relationship between work environment and symptoms of Sick Building Syndrome in employees of BPJS Kesehatan Depok City in 2019. The study used a quantitative method with a cross sectional study design. The population in this study were 70 employees with the sample used total sampling method. Physical environment variables were obtained based on the results of environmental measurements, while non-physical environment variables and individual characteristics with questionnaires. Data analysis used Chi Square test and Fisher's Exact test. The results show that there were a relationship between lighting $(p=0.001)$, age $(p=0.006)$, psychosocial conditions (0.025), smoking habits $(p=0.025)$, and history of diseases $(p=$ $0.038)$ with symptoms of SBS. Variables that not related to SBS symptoms were work climate $(p=$ $0.191)$, work relations of employees and superiors $(p=0.447)$, work relations between employees $(p=$ $1.000)$, sex $(p=0.506)$, and work period $(p=1.000)$. Based on these results, the most common symptoms of SBS were sleepiness and individual characteristics have a relationship with symptoms of SBS. Recommendation for BPJS Kesehatan Depok City are improve the lighting, stretching between working hours, and do a medical check-up to improve employees comfort at work.
\end{abstract}

Keywords: SBS, physical work environment, non physical work environment

\begin{abstract}
ABSTRAK
Sick Building Syndrome (SBS) merupakan kumpulan keluhan yang dirasakan oleh pegawai yang bekerja di dalam ruangan dengan kualitas udara yang kurang baik. Pegawai BPJS Kesehatan Kota Depok bekerja dalam ruangan yang tertutup dengan pencahayaan dan iklim kerja yang kurang baik sehingga berpotensi mengalami gejala seperti kelelahan, sakit kepala, dan nyeri punggung. Tujuan penelitian ini menganalisis hubungan lingkungan kerja dengan gejala Sick Building Syndrome pada pegawai BPJS Kesehatan Kota Depok tahun 2019. Penelitian menggunakan metode kuantitatif dengan desain studi cross sectional. Populasi dalam penelitian ini berjumlah 70 orang pegawai dengan sampel menggunakan metode total sampling. Variabel lingkungan fisik diperoleh berdasarkan hasil pengukuran lingkungan, sedangkan variabel lingkungan non fisik dan karakteristik individu menggunakan kuesioner. Analisis data menggunakan uji Chi Square dan uji Fisher's Exact. Hasil penelitian menunjukkan terdapat hubungan antara pencahayaan $(\mathrm{p}=0,001)$, umur $(\mathrm{p}=0,006)$, kondisi psikososial $(0,025)$, kebiasaan merokok $(\mathrm{p}=0,025)$, dan riwayat penyakit $(\mathrm{p}=0,038)$ dengan gejala SBS. Variabel yang tidak berhubungan dengan gejala SBS adalah iklim kerja $(\mathrm{p}=0,191)$, hubungan kerja pegawai dan atasan $(\mathrm{p}=0,447)$, hubungan kerja antar pegawai $(\mathrm{p}=1,000)$, jenis kelamin $(\mathrm{p}=0,506)$, dan masa kerja $(\mathrm{p}=1,000)$. Berdasarkan hasil tersebut, gejala SBS yang paling banyak adalah kantuk dan karakteristik individu memiliki hubungan dengan gejala SBS. Saran untuk BPJS Kesehatan Kota Depok adalah memperbaiki pencahayaan, melakukan peregangan di sela jam kerja, dan melakukan medical check up untuk meningkatkan kenyamanan pegawai dalam bekerja.
\end{abstract}

Kata Kunci: SBS, lingkungan kerja fisik, lingkungan kerja non fisik 


\section{PENDAHULUAN}

Indonesia saat ini memasuki era industrialisasi dengan pembangunan infrastruktur semakin berkembang pesat terutama kebutuhan akan pembangunan perkantoran menjadi meningkat. Padatnya penduduk di Indonesia sehingga dibuatlah desain perkantoran yang memanfaatkan lahan kecil. Disisi lain hal tersebut dapat mengganggu kualitas udara di dalam ruangan (Camelia, 2011).

Occupational Safety and Health Administration (OSHA) menjelaskan bahwa kualitas udara di dalam ruangan terganggu karena ventilasi yang tidak memadai (52\%), terdapat sumber kontaminasi di dalam ruangan $(16 \%)$ dan di luar ruangan (10\%), adanya mikroba $(5 \%)$, bahan tercemar dari material bangunan (4\%), dan lainnya (13\%) (OSHA, 2011). Keadaan tersebut dapat diperparah jika bangunan menggunakan Air Conditioner (AC) yang tidak terawat (Saptorini dan Rimawati, 2010). Menurut Environmental Protection Agency of America (EPA), bangunan yang menggunakan AC dapat menumbuhkan bakteri patogen Legionella yang dapat menyebabkan penyakit Legionellosis dan Sick Building Syndrome (SBS) (EPA, 2016).

Sick building syndrome merupakan kumpulan keluhan yang dirasakan oleh pegawai yang bekerja di dalam ruangan dengan kualitas udara yang kurang baik (Juarsih, 2013). Pegawai yang memiliki gejala SBS dapat diketahui dengan tanda-tanda yang timbul pada satu atau beberapa pegawai di dalam ruangan yang sama dan tanda-tanda terjadi hanya pada saat berada di dalam ruangan dan menghilang jika berada di luar ruangan .

Faktor terjadinya SBS tersebut dipengaruhi oleh lingkungan fisik dan karakteristik individu. Kondisi psikososial dan riwayat penyakit juga dapat menjadi pemicu munculnya gejala SBS. Riwayat penyakit yang paling banyak menimbulkan gejala SBS adalah alergi (Murniati, 2018). Selain itu, salah satu karakteristik individu yang dapat mempengaruhi timbulnya gejala SBS adalah jenis kelamin (Jafari et al., 2015).

Studi pendahuluan dengan mewawancarai tujuh orang pegawai di BPJS Kesehatan Kota Depok yang bekerja pada pencahayaan yang kurang baik sehingga dapat menimbulkan keluhan seperti kelelahan, sakit kepala, dan nyeri punggung. Hal tersebut berpengaruh terhadap kualitas udara di dalam ruangan (BPJS Kesehaan Kota Depok, 2019). Berdasarkan permasalahan tersebut, maka tujuan penelitian ini adalah untuk menganalisis hubungan lingkungan kerja dengan gejala Sick Bulding Syndrome pada pegawai BPJS Kesehatan Kota Depok tahun 2019.

\section{METODE PENELITIAN}

Penelitian ini menggunakan metode kuantitatif dengan jenis survey analitik. Desain yang digunakan adalah studi cross sectional karena pada penelitian ini variabel independen dan dependen diamati dalam waktu (periode) yang sama. Variabel dependen pada penelitian ini adalah gejala SBS pada Pegawai BPJS Kesehatan Kota Depok. Variabel independen pada penelitian ini adalah lingkungan fisik seperti pencahayaan dan iklim kerja, lingkungan non fisik seperti hubungan kerja pegawai dengan atasan dan hubungan kerja antar pegawai serta karakteristik individu seperti umur, jenis kelamin, masa kerja, kondisi psikososial, kebiasaan merokok, dan riwayat penyakit.

Populasi dalam penelitian ini berjumlah 70 orang pegawai BPJS Kesehatan Kota Depok. Penelitian ini menggunakan metode total sampling, sehingga sampel yang digunakan adalah 70 orang. Alat ukur yang digunakan adalah kuesioner, lux meter, dan heat stress meter. Analisis data dilakukan dengan menggunakan program software pengolahan data statitik. Pada penelitian ini, untuk analisis bivariat menggunakan Uji Chi Square dan Fisher's Exact Test. 


\section{HASIL}

\section{Gejala Sick Building Syndrome}

Tabel 1. Distribusi Responden Berdasarkan Gejala Sick Building Syndrome pada Pegawai BPJS Kesehatan Kota Depok Tahun 2019

\begin{tabular}{|c|c|c|}
\hline Gejala SBS & N & Persentase (\%) \\
\hline Ya & 59 & 84,3 \\
Tidak & 11 & 15,7 \\
\hline Total & 70 & $100 \%$ \\
\hline
\end{tabular}

Berdasarkan hasil penelitian Kesehatan Kota Depok yang mengalami gejala menunjukkan bahwa lebih banyak pegawai $\quad$ SBS terdiri dari 59 orang $(84,3 \%)$.

BPJS Kesehatan Kota Depok yang mengalami gejala SBS. Pegawai BPJS

Tabel 2. Distribusi Responden Berdasarkan Keluhan Gejala Sick Building Syndrome pada Pegawai BPJS Kesehatan Kota Depok Tahun 2019

\begin{tabular}{|c|c|c|c|c|c|}
\hline \multirow{2}{*}{ No } & \multirow{2}{*}{ Gejala SBS } & \multicolumn{2}{|c|}{ Ya } & \multicolumn{2}{|c|}{ Tidak } \\
\hline & & $\mathbf{N}$ & $\%$ & $\mathbf{N}$ & $\%$ \\
\hline 1 & Sakit kepala & 36 & 51,4 & 34 & 48,6 \\
\hline 2 & Nyeri punggung & 37 & 52,9 & 33 & 47,1 \\
\hline 3 & Kantuk & 48 & 68,6 & 22 & 31,4 \\
\hline 4 & Tangan kram & 23 & 32,9 & 47 & 67,1 \\
\hline 5 & Iritasi mata & 29 & 41,4 & 41 & 58,6 \\
\hline 6 & Iritasi tenggorokan & 23 & 32,9 & 47 & 67,1 \\
\hline 7 & Kaki dan tangan gatal & 23 & 32,9 & 47 & 67,1 \\
\hline 8 & Masalah pendengaran & 17 & 24,3 & 53 & 75,7 \\
\hline 9 & Otot berkedut & 18 & 25,7 & 52 & 74,3 \\
\hline 10 & Kaku lengan & 19 & 27,1 & 51 & 72,9 \\
\hline 11 & Iritasi hidung & 19 & 27,1 & 51 & 72,9 \\
\hline 12 & Sakit leher & 27 & 38,6 & 43 & 61,4 \\
\hline 13 & Kaki kram & 21 & 30 & 49 & 70 \\
\hline 14 & Kulit kering & 17 & 24,3 & 53 & 75,7 \\
\hline 15 & Perubahan warna kulit & 17 & 24,3 & 53 & 75,7 \\
\hline 16 & Ruam & 13 & 18,6 & 57 & 81,4 \\
\hline 17 & Kulit gatal & 19 & 27,1 & 51 & 72,9 \\
\hline 18 & Mental kelelahan & 18 & 25,7 & 52 & 74,3 \\
\hline 19 & Kehilangan memori & 17 & 24,3 & 53 & 75,7 \\
\hline 20 & Konsentrasi buruk & 23 & 32,9 & 47 & 67,1 \\
\hline 21 & Membran mukosa kering & 14 & 20 & 56 & 80 \\
\hline 22 & Mual & 18 & 25,7 & 52 & 74,3 \\
\hline 23 & Mencium bau-bauan & 19 & 27,1 & 51 & 72,9 \\
\hline 24 & Sesak dada & 15 & 21,4 & 55 & 78,6 \\
\hline 25 & Stres tingkat tinggi & 19 & 27,1 & 51 & 72,9 \\
\hline 26 & Kelelahan & 38 & 54,3 & 32 & 45,7 \\
\hline
\end{tabular}


Gejala SBS memiliki beberapa keluhan. Keluhan yang diteliti pada pegawai BPJS Kesehatan Kota Depok Tahun 2019, menunjukkan bahwa lebih banyak pegawai yang merasakan kantuk sebesar 48 orang $(68,6 \%)$, kelelahan sebesar 38 orang $(54,3 \%)$, nyeri punggung sebesar 37 orang $(52,9 \%)$, dan sakit kepala sebesar 36 orang $(51,4 \%)$.

Lingkungan Fisik, Lingkungan Non Fisik, Karakteristik Individu

Lingkungan fisik terdiri dari beberapa aspek seperti pencahayaan, iklim kerja, suhu, kelembaban, kebisingan, dan lain lain. Pada penelitian ini hanya meneliti tentang pencahayaan dan iklim kerja. Pengukuran lingkungan non fisik pada penelitian ini hanya meneliti tentang hubungan kerja pegawai dengan atasan dan hubungan kerja antar pegawai. Karakteristik individu merupakan aspek penting terhadap kesehatan pegawai itu sendiri. Oleh karena itu, dilakukan penelitian mengenai umur, jenis kelamin, masa kerja, kondisi psikososial, kebiasaan merokok, dan riwayat penyakit.

Tabel 3. Distribusi Pengukuran Lingkungan Fisik, Lingkungan Non Fisik, Karakteristik Individu di dalam Ruangan BPJS Kesehatan Kota Depok Tahun 2019

\begin{tabular}{|c|c|c|c|c|}
\hline No & Variabel & Kategori & $\mathbf{N}$ & Persentase (\%) \\
\hline \multirow{2}{*}{1.} & \multirow{2}{*}{ Pencahayaan } & Tidak Sesuai & 50 & 71,4 \\
\hline & & Sesuai & 20 & 28,6 \\
\hline \multirow{2}{*}{2.} & \multirow{2}{*}{ Iklim Kerja } & Tidak Sesuai & 58 & 82,9 \\
\hline & & Sesuai & 12 & 17,1 \\
\hline \multirow{2}{*}{3.} & \multirow{2}{*}{ Hubungan kerja pegawai dan atasan } & Kurang & 36 & 51,4 \\
\hline & & Baik & 34 & 48,6 \\
\hline \multirow{2}{*}{4.} & \multirow{2}{*}{ Hubungan kerja antar pegawai } & Kurang & 41 & 58,6 \\
\hline & & Baik & 29 & 41,4 \\
\hline \multirow{2}{*}{5.} & \multirow{2}{*}{ Umur } & $<30$ tahun & 46 & $65,7 \%$ \\
\hline & & $\geq 30$ tahun & 24 & $34,3 \%$ \\
\hline \multirow{2}{*}{6.} & \multirow{2}{*}{ Jenis Kelamin } & Perempuan & 41 & $58,6 \%$ \\
\hline & & Laki-laki & 29 & $41,4 \%$ \\
\hline \multirow{2}{*}{7.} & \multirow{2}{*}{ Masa Kerja } & $>1$ tahun & 47 & $67,1 \%$ \\
\hline & & $\leq 1$ tahun & 23 & $32,9 \%$ \\
\hline \multirow{2}{*}{8.} & \multirow{2}{*}{ Kondisi Psikososial } & Kurang & 65 & $92,9 \%$ \\
\hline & & Baik & 5 & $7,1 \%$ \\
\hline \multirow[b]{2}{*}{9.} & \multirow[b]{2}{*}{ Kebiasaan Merokok } & Ya & 13 & $18,6 \%$ \\
\hline & & Tidak & 57 & $81,4 \%$ \\
\hline \multirow{2}{*}{10.} & \multirow{2}{*}{ Riwayat Penyakit } & Akut & 36 & $51,4 \%$ \\
\hline & & Kronis & 34 & $48,6 \%$ \\
\hline
\end{tabular}

Pada tabel 3, pengukuran lingkungan fisik pada penelitian ini hanya mengukur tentang pencahayaan dan iklim kerja. Terdapat 50 pegawai $(71,4 \%)$ BPJS Kesehatan Kota Depok yang menempati ruang kerja dengan pencahayaan tidak sesuai dengan standar Permenaker No 5 tahun 2018. Sedangkan, terdapat 58 pegawai $(82,9 \%)$ BPJS Kesehatan Kota Depok yang memiliki ruangan dengan iklim kerja tidak sesuai standar Permenaker No 5 tahun 2018.

Pengukuran lingkungan non fisik terhadap 70 pegawai BPJS Kesehatan Kota Depok berdasarkan hasil pengukuran menunjukkan bahwa hubungan kerja pegawai dan atasan sebagian besar berkategori kurang yaitu 36 orang $(51,4 \%)$. Pada variabel hubungan kerja antar pegawai juga menunjukkan bahwa sebagaian besar responden berkategori kurang yaitu 41 orang $(58,6 \%)$.

Karakteristik individu merupakan aspek penting terhadap kesehatan pegawai. Oleh karena itu, dilakukan penelitian mengenai umur, jenis kelamin, masa kerja, kondisi psikososial, kebiasaan merokok, dan riwayat penyakit. Pada variabel umur, pegawai paling banyak berkategori umur $<30$ tahun yaitu 46 orang $(65,7 \%)$. Variabel lain di dalam karakteristik individu adalah jenis kelamin. Jenis kelamin pegawai BPJS Kesehatan Kota Depok sebagian besar adalah perempuan yaitu 
41 orang $(58,6 \%)$. Kemudian terdapat variabel masa kerja, hasil penelitian menunjukkan bahwa kategori masa kerja >1 tahun lebih banyak yaitu 47 orang $(67,1 \%)$.

Kondisi psikososial pegawai BPJS Kesehatan Kota Depok menunjukkan hasil sebagian besar pada kategori kurang yaitu 65 orang $(92,9 \%)$. Variabel kebiasaan merokok menunjukkan bahwa pegawai yang tidak memiliki kebiasaan merokok lebih banyak daripada yang memiliki kebiasaan merokok yaitu 57 orang $(81,4 \%)$. Selanjutnya, riwayat penyakit pegawai BPJS Kesehatan Kota Depok terbagi menjadi dua kategori yaitu akut dan kronis. Kategori akut lebih banyak daripada kategori kronis yaitu 36 orang $(51,4 \%)$.

Hubungan Lingkungan Fisik dengan Gejala SBS

Tabel 4. Hubungan Lingkungan Fisik dengan Gejala SBS pada Pegawai BPJS Kesehatan Kota Depok Tahun 2019

\begin{tabular}{|c|c|c|c|c|c|c|c|c|}
\hline \multirow{3}{*}{ No. } & \multirow{3}{*}{ Variabel } & \multicolumn{4}{|c|}{ SBS } & \multirow{3}{*}{$\mathbf{N}$} & \multirow{3}{*}{$\%$} & \multirow{3}{*}{$p$ value } \\
\hline & & \multicolumn{2}{|c|}{ Ya } & \multicolumn{2}{|c|}{ Tidak } & & & \\
\hline & & $\mathbf{N}$ & $\%$ & $\mathbf{N}$ & $\%$ & & & \\
\hline 1. & $\begin{array}{l}\text { Pencahayaan } \\
\text { Tidak Sesuai } \\
\text { Sesuai }\end{array}$ & $\begin{array}{l}47 \\
12\end{array}$ & $\begin{array}{l}94 \\
60\end{array}$ & $\begin{array}{l}3 \\
8\end{array}$ & $\begin{array}{c}6 \\
40\end{array}$ & $\begin{array}{l}50 \\
20\end{array}$ & $\begin{array}{l}100 \\
100\end{array}$ & 0,001 \\
\hline 2. & $\begin{array}{l}\text { Iklim Kerja } \\
\text { Tidak Sesuai } \\
\text { Sesuai }\end{array}$ & $\begin{array}{l}47 \\
12\end{array}$ & $\begin{array}{c}81 \\
100\end{array}$ & $\begin{array}{c}11 \\
0\end{array}$ & $\begin{array}{c}19 \\
0\end{array}$ & $\begin{array}{l}58 \\
12\end{array}$ & $\begin{array}{l}100 \\
100\end{array}$ & 0,191 \\
\hline
\end{tabular}

Hasil uji statistik lingkungan fisik BPJS Kesehatan Kota Depok terbagi menjadi dua yaitu pengukuran pencahayaan dengan kategori tidak sesuai yang mengalami SBS sebesar 47 orang $(94 \%)$ dan kategori sesuai yang mengalami SBS sebesar 12 orang $(60 \%)$. Nilai p dari variabel pencahayaan adalah 0,001 berarti ada hubungan yang bermakna antara

pencahayaan dengan gejala SBS. Kemudian untuk pengukuran iklim kerja dengan kategori tidak sesuai yang mengalami SBS sebanyak 47 orang $(81 \%)$ dan kategori sesuai yang mengalami SBS sebanyak 12 orang (100\%). Nilai $\mathrm{p}$ dari variabel iklim kerja adalah 0,191 berarti tidak ada hubungan yang bermakna antara iklim kerja dengan gejala SBS.

\section{Hubungan Lingkungan Non Fisik dengan Gejala SBS}

Tabel 5. Hubungan Lingkungan Non Fisik Gejala SBS pada Pegawai BPJS Kesehatan Kota Depok Tahun 2019

\begin{tabular}{|c|c|c|c|c|c|c|c|c|}
\hline \multirow{3}{*}{ No. } & \multirow{3}{*}{ Variabel } & \multicolumn{4}{|c|}{ SBS } & \multirow{3}{*}{$\mathbf{N}$} & \multirow{3}{*}{$\%$} & \multirow{3}{*}{$\begin{array}{c}p \\
\text { value }\end{array}$} \\
\hline & & \multicolumn{2}{|c|}{ Ya } & \multicolumn{2}{|c|}{ Tidak } & & & \\
\hline & & $\mathbf{N}$ & $\%$ & $\mathbf{N}$ & $\%$ & & & \\
\hline 1. & $\begin{array}{l}\text { Hubungan kerja pegawai dan atasan } \\
\text { Kurang } \\
\text { Baik }\end{array}$ & $\begin{array}{l}32 \\
27\end{array}$ & $\begin{array}{l}88,9 \\
79,4\end{array}$ & $\begin{array}{l}4 \\
7\end{array}$ & $\begin{array}{l}11,4 \\
20,6\end{array}$ & $\begin{array}{l}36 \\
34\end{array}$ & $\begin{array}{l}100 \\
100\end{array}$ & 0,447 \\
\hline 2. & $\begin{array}{l}\text { Hubungan kerja antar pegawai } \\
\text { Kurang } \\
\text { Baik }\end{array}$ & $\begin{array}{l}34 \\
25\end{array}$ & $\begin{array}{l}82,9 \\
86,2\end{array}$ & $\begin{array}{l}7 \\
4\end{array}$ & $\begin{array}{l}17,1 \\
13,8\end{array}$ & $\begin{array}{l}41 \\
29\end{array}$ & $\begin{array}{l}100 \\
100\end{array}$ & 1,000 \\
\hline
\end{tabular}

Berdasarkan hasil uji statistik tentang hubungan kerja pegawai dan atasan pada kategori kurang yang mengalami gejala SBS sebanyak 32 orang $(88,9 \%)$. Sedangkan, hubungan kerja pegawai dan atasan pada kategori baik yang mengalami gejala SBS sebanyak 27 orang $(79,4 \%)$. Nilai $p$ dari variabel hubungan kerja pegawai dan atasan adalah 0,447 berarti tidak ada hubungan yang bermakna antara hubungan kerja pegawai dengan atasan dengan gejala SBS.
Kemudian, hasil analisis hubungan kerja antar pegawai pada kategori kurang yang mengalami gejala SBS sebanyak 34 orang $(82,9 \%)$. Sedangkan, hubungan kerja antar pegawai pada kategori baik yang mengalami gejala SBS sebanyak 26 orang $(86,4 \%)$. Nilai $p$ dari variabel hubungan kerja antar pegawai adalah 1,000 berarti tidak ada hubungan yang bermakna antara hubungan kerja antar pegawai dengan gejala SBS. 
Pegawai BPJS Kesehatan Depok Tahun 2019

\section{Hubungan Karakteristik Individu dengan Gejala SBS}

Tabel 6. Hubungan Karakteristik Individu dengan Gejala SBS pada Pegawai BPJS Kesehatan Kota Depok Tahun 2019

\begin{tabular}{|c|c|c|c|c|c|c|c|c|}
\hline \multirow{3}{*}{ No. } & \multirow{3}{*}{ Variabel } & \multicolumn{4}{|c|}{ SBS } & \multirow{3}{*}{$\mathbf{N}$} & \multirow{3}{*}{$\%$} & \multirow{3}{*}{$\begin{array}{c}p \\
\text { value }\end{array}$} \\
\hline & & \multicolumn{2}{|c|}{ Ya } & \multicolumn{2}{|c|}{ Tidak } & & & \\
\hline & & $\mathbf{N}$ & $\%$ & $\mathbf{N}$ & $\%$ & & & \\
\hline \multirow[t]{3}{*}{1.} & Umur & & & & & & & \multirow{3}{*}{0,006} \\
\hline & $<30$ tahun & 43 & 93,5 & 3 & 6,5 & 46 & 100 & \\
\hline & $\geq 30$ tahun & 14 & 66,7 & 8 & 33,3 & 24 & 100 & \\
\hline \multirow[t]{3}{*}{2.} & Jenis Kelamin & & & & & & & \multirow{3}{*}{0,506} \\
\hline & Perempuan & 36 & 87,8 & 5 & 12,2 & 41 & 100 & \\
\hline & Laki-laki & 23 & 79,3 & 6 & 20,7 & 29 & 100 & \\
\hline \multirow[t]{3}{*}{3.} & Masa Kerja & & & & & & & \multirow{3}{*}{1,000} \\
\hline & $>1$ tahun & 40 & 85,1 & 7 & 14,9 & 47 & 100 & \\
\hline & $\leq 1$ tahun & 19 & 82,6 & 4 & 17,4 & 23 & 100 & \\
\hline \multirow[t]{3}{*}{4.} & Kondisi Psikososial & & & & & & & \multirow{3}{*}{0,025} \\
\hline & Kurang & 57 & 87,7 & 8 & 12,3 & 65 & 100 & \\
\hline & Baik & 2 & 40 & 3 & 60 & 5 & 100 & \\
\hline \multirow[t]{3}{*}{5.} & Kebiasaan Merokok & & & & & & & \multirow{3}{*}{0,025} \\
\hline & & 8 & 61,5 & 5 & 38,5 & 13 & 100 & \\
\hline & Tidak & 51 & 89,5 & 6 & 10,5 & 57 & 100 & \\
\hline \multirow[t]{3}{*}{6} & Riwayat Penyakit & & & & & & & \multirow{3}{*}{0,038} \\
\hline & Akut & 34 & 94,4 & 2 & 5,6 & 36 & 100 & \\
\hline & Kronis & 25 & 73,5 & 9 & 26,5 & 34 & 100 & \\
\hline
\end{tabular}

Pada karakteristik individu dilakukan analisis pegawai dengan umur $<30$ tahun yang mengalami gejala SBS sebanyak 43 orang $(93,5 \%)$ sedangkan, pegawai dengan umur $\geq 30$ tahun yang mengalami gejala SBS sebanyak 14 orang $(66,7 \%)$. Nilai $\mathrm{p}$ dari variabel umur adalah 0,01 berarti ada hubungan yang bermakna antara umur dengan gejala SBS. Hasil analisis karakteristik individu lainnya adalah jenis kelamin perempuan yang mengalami gejala SBS sebanyak 36 orang $(87,8 \%)$ dan jenis kelamin laki-laki yang mengalami gejala SBS sebanyak 23 orang $(79,3 \%)$ Nilai p dari variabel jenis kelamin adalah 0,506 berarti tidak ada hubungan yang bermakna antara jenis kelamin dengan gejala SBS. Hasil analisis pegawai dengan masa kerja $>1$ tahun yang mengalami gejala SBS sebanyak 40 orang $(85,1 \%)$. Sedangkan pegawai dengan masa kerja $\leq 1$ tahun yang mengalami gejala SBS sebanyak 19 orang $(82,6 \%)$. Nilai $\mathrm{p}$ dari variabel masa kerja adalah 1,000 yang berarti tidak ada hubungan yang bermakna antara masa kerja dengan gejala SBS.

Kondisi psikososial pada karakteristik inidividu terbagi menajdi dua yaitu kategori kurang yang mengalami gejala SBS sebanyak 57 orang $(87,7 \%)$ dan kategori baik yang mengalami gejala SBS sebanyak 2 orang
(40\%). Nilai p dari variabel kondisi psikososial adalah 0,025 yang berarti ada hubungan yang bermakna antara kondisi psikososial dengan gejala SBS.

Kemudian, hasil analisis pegawai yang memiliki kebiasaan merokok dan mengalami gejala SBS sebanyak 51 orang $(89,5 \%)$. Sedangkan, pegawai yang tidak memiliki kebiasaan merokok tetapi mengalami gejala SBS sebanyak 8 orang $(61,5 \%)$. Nilai p dari variabel kebiasaan merokok adalah 0,025 yang berarti ada hubungan yang bermakna antara kebiasaan merokok dengan gejala SBS.

Selanjutnya, hasil analisis pegawai dengan riwayat penyakit akut yang mengalami gejala SBS sebanyak 34 orang $(94,4 \%)$ dan pegawai dengan riwayat penyakit kronis yang mengalami gejala SBS sebanyak 25 orang $(73,5 \%)$. Nilai $p$ dari variabel riwayat penyakit adalah 0,038 yang berarti ada hubungan yang bermakna antara riwayat penyakit dengan gejala SBS.

\section{PEMBAHASAN}

\section{Gejala Sick Building Syndrome}

Berdasarkan hasil penelitian menunjukkan bahwa lebih banyak pegawai BPJS Kesehatan Kota Depok yang mengalami gejala SBS. Keluhan paling banyak adalah kantuk, kelelahan, nyeri punggung, dan sakit 
Annisa, et al. Hubungan Lingkungan Kerja Dengan Gejala Sick Building Syndrome Pada Pegawai BPJS Kesehatan Depok Tahun 2019

kepala. Hal tersebut terjadi karena terlalu banyaknya pekerjaan yang dilakukan sehingga menimbulkan gejala tersebut. Banyak pegawai yang mengalami kebosanan saat bekerja karena pekerjaan yang terlalu monoton dan tidak ada sesi peregangan di sela jam kerja sehingga menimbulkan kantuk dan kelelahan. Pegawai juga sering mengeluhkan sakit nyeri punggung karena terlalu lama bekerja dan posisi duduk yang kurang nyaman. Terdapat juga pegawai yang mengeluhkan sakit kepala karena terlalu banyaknya tekanan pekerjaan dari atasan.

Hal ini sejalan dengan penelitian lain bahwa gejala SBS paling banyak yang dikeluhkan adalah mengantuk. Terlalu banyaknya pekerjaan dan lingkungan kerja yang jenuh dapat membuat pegawai merasakan kelelahan dan kantuk. Sehingga hal tersebut harus dapat diantisipasi agar tidak menimbulkan gejala yang berkelanjutan (Rahman, 2013). Hasil penelitian lainnya juga sejalan, bahwa gejala SBS yang paling banyak adalah iritasi membran mukosa seperti sakit kepala dan kelelahan. Sakit kepala dan kelelahan dapat terjadi karena terlalu banyaknya tekanan pekerjaan dari atasan untuk menyelesaikan pekerjaan sesuai batas yang ditentukan. Hal tersebut dapat mempengaruhi kenyamanan pegawai dalam bekerja (Fauzan, Jalaludin dan Choo Chua, 2016).

\section{Lingkungan Fisik Pencahayaan}

Berdasarkan hasil tabulasi silang terdapat pegawai yang berada diruangan dengan pencahayaan sesuai standar tetapi mengalami gejala SBS. Hal tersebut terjadi karena terdapat beberapa pegawai yang memiliki riwayat penyakit, sehingga mengalami gejala SBS walaupun berada diruangan dengan pencahayaan sesuai standar. Kasus lain di BPJS Kesehatan Kota Depok yaitu hanya satu ruangan yang diberi pencahayaan dengan lampu neon tetapi untuk ruangan lainnya hanya menggunakan lampu bohlam. Sehingga pencahayaannya kurang dari standar dan menyebabkan kelelahan mata serta menimbulkan ketidaknyamanan bagi pegawai BPJS Kesehatan Kota Depok.

Hal ini sejalan dengan penelitian lain yang mengukur pencahayaan di dalam ruangan. Hasil penelitian tersebut menunjukkan bahwa ada hubungan pencahayaan dengan gejala SBS. Pencahayaan
JPH RECODE Oktober 2019;3 (1) : 44-54 http://e-journal.unair.ac.id/JPHRECODE

yang terlalu tinggi dan terlalu rendah dapat menjadi faktor pemicu timbulnya gejala SBS. Pencahayaan yang tidak sesuai dengan standar dapat mengganggu kenyamanan dalam bekerja dan memaksakan akomodasi mata untuk melihat (Hartoyo, 2009). Peneliti lainnya juga sejalan, bahwa pencahayaan yang buruk terutama pada siang hari dapat menjadi salah satu faktor penyebab gejala SBS. Apabila hal ini terus terjadi maka akan mengganggu pegawai dalam melakukan pekerjaannya dan membahayakan kesehatan pegawai tersebut (Chalaris et al., 2010).

\section{Iklim Kerja}

Kasus pada pegawai BPJS Kesehatan Kota Depok berdasarkan hasil tabulasi silang menyatakan bahwa $100 \%$ pegawai yang berada pada ruang dengan iklim kerja sesuai dengan standar mengalami gejala SBS. Hal tersebut dapat terjadi karena gejala SBS tidak hanya dipengaruhi oleh lingkungan fisik saja tetapi dapat dipengaruhi dari lingkungan non fisiknya. Lingkungan non fisik memiliki pengaruh yang lebih besar terhadap gejala SBS dibandingkan lingkungan fisik. Oleh karena itu, dapat memungkinkan pegawai tersebut terkena gejala SBS.

Hal ini tidak sejalan dengan hasil penelitian lain yang menyatakan bahwa, apabila hasil pengukuran iklim kerja hampir semua tidak sesuai dengan standar maka akan mempengaruhi kenyamanan pegawai dalam bekerja dan memiliki hubungan dengan gejala SBS (Tritama, Rachman dan Dermawan, 2009). Tetapi menurut peneliti lainnya mengatakan iklim kerja bukan satu-satunya faktor yang dapat menyebabkan gejala SBS. Terdapat faktor lain yang mengikuti sehingga dapat terjadinya gejala SBS. Oleh karena itu, apabila iklim kerja di dalam ruangan tidak sesuai standar tetapi tidak ada hubungannya dengan gejala SBS bisa terjadi karena faktor lainnya. Semakin lama masa kerjanya seorang pegawai maka kemungkinan besar pegawai tersebut sudah bisa menyesuaikan diri dengan iklim kerja yang ada pada tempat kerjanya sehingga hal ini bisa terjadi (Apriyani, 2014).

\section{Lingkungan Non Fisik}

\section{Hubungan Kerja Pegawai dan Atasan}

Pada hasil tabulasi silang dikatakan bahwa terdapat juga hubungan kerja pegawai dan atasan yang berkategori baik namun mengalami gejala SBS. Hal tersebut 
Annisa, et al. Hubungan Lingkungan Kerja Dengan Gejala Sick Building Syndrome Pada Pegawai BPJS Kesehatan Depok Tahun 2019

dikarenakan banyak pegawai BPJS Kesehatan Kota Depok yang memiliki keluhan lain seperti kondisi psikososialnya yang terganggu karena terlalu banyak tekanan dalam pekerjaannya. Kaus lain pada pegawai BPJS Kesehatan Kota Depok adalah terlalu banyaknya pegawai yang beraktivitas diluar ruangan sehingga kurangnya interaksi antara pegawai dan atasan menyebabkan tidak adanya hubungan yang signifikan dengan gejala SBS.

Hal ini tidak sejalan penelitian Rahmawanti, dkk (2014) yang menyakatan bahwa penyampaian informasi dari pimpinan ke bawahan dapat berpengaruh terhadap kenyamanan kedua belah pihak dan dapat meningkatkan kinerjanya (Rahmawanti, Swasto dan Prasetya, 2014). Peneliti lain mengatakan hubungan kerja pegawai dengan atasan dan hubungan kerja antar pegawai memiliki pengaruh yang lebih besar daripada lingkungan fisik. Hal tersebut dikarenakan hubungan personal yang terjalin dapat memberikan pengaruh terhadap kinerja pegawai (Setyadi, Utami dan Nurtjahjono, 2015).

\section{Hubungan Kerja Antar Pegawai}

Pada kasus pegawai BPJS Kesehatan

Kota Depok masa kerja $<1$ tahun tidak memiliki hubungan dengan gejala SBS. Hal tersebut terjadi karena terdapat pegawai yang masih sulit untuk berinteraksi satu sama lain. Perbedaan umur antar pegawai BPJS Kesehatan Kota Depok juga mempengaruhi interaksi hubungana kerja antar pegawai yang masih kurang.

Kasus lainnya yaitu dari hasil tabulasi silang menyatakan bahwa hubungan kerja antar pegawai pada kategori baik juga banyak yang mengalami gejala SBS. Hal tersebut terjadi sama halnya dengan hubungan kerja pegawai dan atasan yaitu dari faktor lain selain hubungan lingkungan non fisiknya itu sendiri seperti kondisi psikososial dan riwayat penyakit yang kurang baik.

Hal ini tidak sejalan dengan peneliti lain yang mengatakan bahwa apabila terjadi perselisihan antar pegawai dalam bekerja maka akan mempengaruhi kondisi pegawai dalam bekerja seperti turunnya semangat pegawai (Nitisemito, 2008). Tetapi menurut peneliti lainnya mengatakan, hubungan kerja antar pegawai dapat mempengaruhi kesehatan pegawai. Terdapat beberapa kantor yang memiliki hubungan kerja yang kurang baik,
JPH RECODE Oktober 2019;3 (1) : 44-54 http://e-journal.unair.ac.id/JPHRECODE

sehingga terjadi ketidakseimbangan di dalam lingkungan kerjanya. Hal tersebut dapat membawanya mengalami gejala SBS, namun faktor tersebut dapat dilihat lagi dari kondisi pegawai dan lingkungannya (Yulianti, Ikhsan dan Wiyono, 2012).

\section{Karakteristik Individu Umur}

Hasil penelitian terhadap pegawai BPJS Kesehatan Kota Depok menunjukkan bahwa umur responden bervariasi mulai dari 22 tahun sampai 49 tahun. Pada hasil tabulasi silang, menunjukkan bahwa gejala SBS pada kategori umur < 30 tahun lebih banyak daripada kategori umur $\geq 30$ tahun. Nilai $p$ yang didapat dari hasil uji statistik menujukkan ada hubungan yang bermakna antara kategori umur < 30 tahun dengan gejala SBS pada pegawai BPJS Kesehatan Kota Depok Tahun 2019. Hal ini terjadi karena berdasarkan hasil wawancara dengan beberapa pegawai banyak pegawai yang berkategori umur $<30$ tahun sering menghabiskan waktunya di dalam gedung dengan banyak pekerjaan yang harus dilakukan sehingga lebih mudah terkena gejala SBS.

Keadaan ini sejalan dengan penelitian lain bahwa sebagian besar pegawai yang merasakan gejala SBS pada usia muda. Responden yang berusia muda lebih banyak menghabiskan waktu di dalam gedung daripada diluar gedung karena biasanya pegawai yang berusia muda masih menjadi pegawai baru. Sehingga mengharuskan pegawai baru lebih banyak belajar dan bekerja di dalam gedung (Verayani, 2018).

Menurut penelitian lainnya juga sejalan, bahwa umur muda ikut berperan dalam timbulnya gejala SBS. Umur muda merupakan umur produktif dimana dalam usia ini biasanya pegawai dituntut untuk meningkatkan performanya secara optimal sehingga stamina yang ada pun dapat menurun. Banyaknya pegawai diperkantoran yang berumur muda dengan masa kerja yang lebih lama di dalam ruangan menyebabkan pegawai yang berumur muda juga rentan terhadap gejala SBS (Anies, 2004).

\section{Jenis Kelamin}

Berdasarkan hasil hasil tabulasi silang hal ini terjadi karena pegawai BPJS Kesehatan Kota Depok yang berjenis kelamin perempuan dan laki-laki sama banyaknya mengalami 
gejala SBS. Oleh karena itu, dapat memungkinkan tidak ada hubungan yang bemakna antara jenis kelamin dengan gejala SBS.

Kondisi ini tidak sejalan dengan peneliti lain yang menyatakan bahwa perempuan lebih rentan terkena gejala SBS. Berdasarkan hasil penelitiannya, perempuan lebih mudah merasakan kelelahan dan lebih berisiko terkena penyakit daripada laki-laki. Banyak perbedaan lainnya yang dapat berpengaruh terhadap kerentanan terjadinya suatu penyakit. Seperti ukuran tubuh dan kekuatan otot pegawai perempuan relatif kurang dibandingkan laki-laki. Kondisi hormonal yang dimiliki perempuan juga berbeda dengan laki-laki seperti misalnya siklus haid, hamil dan menopause (Murniati, 2018). Tetapi terdapat penelitian lain yang mengatakan bahwa keluhan malaise merupakan salah satu penyebab gejala SBS paling umum dapat terjadi oleh perempuan maupun laki-laki. Sehingga tidak ada hubungan antara jenis kelammin dengan gejala SBS (Jafari et al., 2015).

\section{Masa Kerja}

Pada hasil penelitian terhadap pegawai

BPJS Kesehatan Kota Depok menunjukkan bahwa masa kerja responden dengan kategori $>1$ tahun lebih banyak daripada kategori masa kerja $\leq 1$ tahun. Nilai $p$ yang didapat dari hasil uji statistik tersebut menujukkan bahwa tidak ada hubungan yang bermakna antara masa kerja dengan gejala SBS pada pegawai BPJS Kesehatan Kota Depok Tahun 2019. Pada kasus ini, pegawai BPJS Kesehatan Kota Depok yang memiliki masa kerja $>1$ tahun lebih banyak bekerja diluar ruangan sehingga jarang merasakan keluhan gejala SBS yang dirasakan di dalam ruangan

Hal ini tidak sejalan dengan teori Raharjo, dkk (2015) yang menyatakan bahwa semakin lama masa kerja pegawai maka semakin banyak dan bermacam-macam informasi masalah kesehatan yang dialami. Masa kerja yang cukup lama mempengaruhi tingkat keterpajanan responden terhadap polusi di dalam ruang dan dapat menimbulkan gejala SBS (Raharjo, Wiediartini dan Dermawan, 2015).

Peneliti lain juga mengatakan bahwa lingkungan kerja yang buruk dan masa kerja dapat mempengaruhi kinerja karyawan. Pada masa kerja >1 tahun dapat memungkinkan tidak memiliki hubungan dengan gejala SBS karena terdapat faktor lainnya seperti kondisi pegawainya itu sendiri (Suma'mur, 2009).

\section{Kondisi Psikososial}

Hasil penelitian terhadap pegawai BPJS Kesehatan Kota Depok menunjukkan bahwa kondisi psikososial dengan kategori kurang lebih besar daripada kategori baik. Nilai $\mathrm{p}$ yang didapat dari hasil uji statistik tersebut menunjukkan ada hubungan yang bermakna antara kondisi prikososial dengan kategori kurang dengan gejala SBS pada pegawai BPJS Kesehatan Kota Depok Tahun 2019. Terlalu banyaknya pekerjaan yang dilakukan oleh pegawai BPJS Kesehatan Kota Depok menyebabkan pegawai mudah lelah dan merasakan stress sehingga menyebabkan gejala SBS lainnya.

Hal ini sejalan dengan penelitian Yulianti, dkk (2012) yang menyatakan bahwa gangguan kesehatan akan mempengaruhi timbulnya gejala SBS. Stress salah satu faktor yang dapat menghambat kuantitas dan kenyamanan saat bekerja (Yulianti, Ikhsan dan Wiyono, 2012). Penelitian lain juga sejalan, bahwa stress kerja dapat mempengaruhi pegawai dalam bekerja. Meningkatnya kesadaran akan stres dalam bekerja membuat hal ini menjadi masalah yang lebih serius terhadap kesehatan. Kondisi psikososial dan lingkungan kerja yang seperti ini sangat berpengaruh terhadap gejala SBS (Hamzah, Jun dan Anua, 2017).

\section{Kebiasaan Merokok}

Pada hasil tabulasi silang mengatakan lebih banyak pegawai yang tidak merokok tetapi mengalami gejala SBS. Hal tersebut dapat terjadi karena ada beberapa pegawai berstatus sebagai perokok pasif yang memungkinkan terkena gejala SBS. Selain itu, terdapat juga pegawai tidak merokok yang memiliki riwayat penyakit asma, sehingga apabila terkena asap rokok bisa menimbulkan gejala SBS.

Hal ini sejalan dengan penelitian lain mengatakan bahwa beberapa pegawai yang merokok mengeluarkan asap rokoknya dan dihirup oleh pegawai yang tidak merokok. Asap rokok memiliki banyak kandungan berbahaya bagi yang menghirupnya. Oleh karena itu, perokok pasif lebih sensitif terkena gejala SBS (Juarsih, 2013). 
Annisa, et al. Hubungan Lingkungan Kerja Dengan Gejala Sick Building Syndrome Pada Pegawai BPJS Kesehatan Depok Tahun 2019

Peneliti lainnya juga sejalan, bahwa asap rokok merupakan bahan pencemar yang bisa menyebabkan seseorang terkena penyakit. Asap rokok memiliki kandungan bahan berbahaya seperti karbonmonoksida. Apabila hal tersebut terus terjadi maka dapat menjadi pencemaran lingkungan. Hal ini memicu timbulnya gejala SBS seperti gangguan pernafasan, mata perih, batuk (Cahyadi, 2010).

\section{Riwayat Penyakit}

Pada kasus pegawai BPJS Kesehatan Kota Depok lebih banyak pegawai yang mempunyai riwayat penyakit akut. Hal tersebut dikarenakan kondisi lingkungan fisik yang kurang baik. Banyak pegawai yang sering mengeluhkan penyakit flu dan insomnia. Penyakit tersebut dapat membawanya mengalami gejala SBS.

Hal ini sejalan dengan penelitian lain yang menyatakan bahwa banyaknya pegawai yang memiliki riwayat penyakit akut karena kondisi lingkungan kerja yang kurang mendukung, sehingga menyebabkan gejala SBS (Usman, 2011). Berdasarkan hasil penelitian lainnya juga sejalan, bahwa riwayat penyakit seperti asma berkaitan dengan timbulnya gejala SBS. Gangguan pernafasan seperti asma disebabkan karena lingkungan kerja yang kurang baik. Suhu dan kelembaban yang tidak sesuai dengan standar menyebabkan lingkungan kerja terganggu dan menyebabkan penyakit bagi pegawai yang ada di dalamnya (Ghaffarianhoseini et al., 2018).

\section{KESIMPULAN}

Berdasarkan hasil penelitian dan pembahasan hubungan lingkungan kerja dengan gejala sick building syndrome pada pegawai BPJS Kesehatan Kota Depok tahun 2019, maka peneliti menarik kesimpulan bahwa pada lingkungan fisik hanya ada hubungan antara pencahayaan dengan gejala SBS dan tidak ada hubungan antara lingkungan non fisik dengan gejala SBS. Penelitian ini juga menunjukkan bahwa pada karakteristik individu hampir semuanya memiliki hubungan dengan gejala SBS. Hasil penelitian juga menunjukkan bahwa pegawai BPJS Kesehatan Kota Depok lebih banyak mengalami gejala SBS dengan keluhan gejala SBS yang paling banyak adalah kantuk dan kelelahan.

\section{SARAN}

JPH RECODE Oktober 2019;3 (1) : 44-54 http://e-journal.unair.ac.id/JPHRECODE

Saran untuk penelitian ini adalah mengganti lampu di ruang kerja pegawai dengan lampu yang lebih terang agar pencahayaan di kantor BPJS Kesehatan Kota Depok sesuai dengan standar baku. Hal lain yang dapat dilakukan adalah meningkatkan hubungan yang lebih baik lagi antara pegawai dan atasan serta antar pegawai itu sendiri dapat dilakukan dengan cara makan bersama selagi istirahat atau diskusi bersama selagi ada waktu luang. Selain itu, melakukan medical check up satu tahun sekali untuk mengetahui kondisi kesehatan pegawai BPJS Kesehatan Kota Depok.

\section{DAFTAR PUSTAKA}

Anies. 2004. Problem Kesehatan Masyarakat dan Sick Building Syndrome. Jakarta: Yarsi.

Apriyani, A. 2014. Pengaruh Iklim Kerja Terhadap Dehidrasi Pada Karyawan Unit Workshop PT. Indo Acidatama Tbk, Kemiri, Kebakkramat, Karanganyar. Jurnal Fakultas Ilmu Kesehatan, hal. 4-17.

Cahyadi. 2010. Pengukuran Lingkungan Fisik Keja Dan Workstation Di Kantor Pos Pusat Samarinda.

Camelia, A. 2011. Sick Building Syndrome and Indoor Air Quality. Jurnal Ilmu Kesehatan Masyarakat, 2(2), hal. 79-84.

Chalaris, M. et al. 2010. Sick Building Syndrome. Journal of Environmental Protection and Ecology, 11(2), hal. 515522.

EPA. 2016. Indoor Air Facts No.4 (revised) Sick Building Syndrome. USA. doi: 10.1136/oem.2003.008813.

Fauzan, N. H., Jalaludin, J. dan Choo Chua, P. 2016. Indoor Air Quality and Sick Building Syndrome (SBS) among Staff in Two Different Private Higher Learning Institution Settings in Kuala Lumpur and Selangor. International Journal of Applied Chemistry, 12(1), hal. 57-61. Tersedia pada: http://www.ripublication.com.

Ghaffarianhoseini, Amirhosein et al. 2018. Sick Building Syndrome: Are We Doing Enough?. Architectural Science Review, 61(3), hal. 99-121. doi: 10.1080/00038628.2018.1461060.

Hamzah, N. A., Jun, K. E. dan Anua, S. M. 2017. Indoor Air Quality and Symptoms 
of Sick Building Syndrome in Two Selected Building (New Versus Old). Journal of Occupational Safety and Health, 14(2), hal. 7-14.

Hartoyo, S. 2009. Faktor lingkungan yang berhubungan dengan kejadian sick building syndrome ( SBS ). hal. 10-13.

Jafari, M. J. et al. 2015. Association of Sick Building Syndrome with Indoor Air Parameters. Tanaffos, 14(1), hal. 55-62.

Juarsih. 2013. Pengaruh Kualitas Fisik Udara Dalam Ruangan Ber AC Terhadap Kejadian Sick Building Syndrome (SBS) Pada Pegawai di Gedung Pusat Teknologi Informasi dan Komunikasi (PUSTIKOM) Universitas Negeri Gorontalo. Jurnal Fakultas Ilmu-Ilmu Kesehatan dan Keolahragaan, 05, hal. $1-6$.

Murniati, N. 2018. Hubungan Suhu dan Kelembaban dengan Keluhan Sick Building Syndrome pada Petugas Administrasi Rumah Sakit Swasta X. Jurnal Ilmu Kesehatan Masyarakat, 07(03), hal. 148-154.

Nitisemito, A. 2008. Manajemen Personalia. Jakarta: Ghalia Indonesia.

OSHA. 2011. Indoor Air Quality in Commercial and Institutional Buildings. OSHA 3430-04. USA. Diakses dari: https://www.osha.gov/Publications/3430 indoor-air-quality-sm.pdf.

Peraturan Menteri Ketenagakerjaan Republik Indonesia Nomor 5 Tahun 2018 tentang Standar Keselamatan Kesehatan Kerja Lingkungan Kerja.

Raharjo, H. D., Wiediartini dan Dermawan, D. 2015. Analisis Pengaruh Karakteristik Individu dan Faktor Fisik Terhadap Gejala Sick Building Syndrome Pada Pegawai di Gedung Utama Perusahaan Fabrikasi Kapal. Jurnal Teknik Keselamatan dan Kesehatan Kerja, (2581), hal. 5-9.

Rahman, N. H. 2013. Studi Tentang Keluhan Sick Building Syndrome (SBS) Pada Pegawai di Gedung Rektorat Universitas Hasanuddin Makassar Tahun 2013. Makassar.

Rahmawanti, N. P., Swasto, B. dan Prasetya, A. 2014. Pengaruh Lingkungan Kerja Terhadap Kinerja Karyawan (Studi pada Karyawan Kantor Pelayanan Pajak Pratama Malang Utara). Jurnal Administrasi Bisnis (JAB), 8(2), hal. 1-
9.

Saptorini, K. K. dan Rimawati, E. 2010. Hubungan Antara Faktor Individu dan Faktor Bangunan Dengan Kejadian Nyeri Kepala Sick Building Syndrome Pada Staf Edukatif di Lingkungan Universitas Dian Nuswantoro Semarang. Jurnal Visikes, 9(1), hal. 10-18.

Setyadi, B., Utami, H. N. dan Nurtjahjono, G. E. 2015. Pengaruh Lingkungan Kerja Fisik dan Non Fisik terhadap Motivasi Kerja dan Kinerja Karyawan (Studi Pada Karyawan PT. Bank BRI, Tbk . Cabang Bogor). Jurnal Administrasi Bisnis (JAB), 21(1), hal. 1-8.

Suma'mur. 2009. Hiegiene Perusahaan dan Keselamatan Kerja. jakarta: CV. Sagung Seto.

Tritama, A. S., Rachman, F. dan Dermawan, D. 2009. Studi Analisis Pengaruh Kondisi Lingkungan Kerja Terhadap Sick Building Syndrome ( SBS ) Pada Karyawan di Gedung Perkantoran Perusahaan Fabrikasi Pipa Abstrak. Jurnal Teknik Keselamatan dan Kesehatan Kerja, (2581), hal. 10-14.

Usman, H. 2011. Faktor-Faktor yang Berhubungan Dengan Kejadian Sick Building Syndrome (SBS) Pada Karyawan PT Bosowa Berlian Motor Makassar. Makassar.

Verayani, E. 2018. Identifikasi Legionella, Kualitas Udara Ruang dan Keluhan Sick Building Syndrome Pada Petugas Instalasi Transfusi Darah RSUD Dr. Soetomo. Jurnal Kesehatan Lingkungan, 10(3), hal. 299-305.

Yulianti, D., Ikhsan, M. dan Wiyono, W. H. 2012. Sick Building Syndrome. Jurnal Fakultas Kedokteran, 39(1), hal. 21-24. 